\title{
Studies on Screening of Paint Degrading Microorganisms Isolated from Wall Scrapings
}

\author{
Yamuna G. ${ }^{1}$, Anooj O. ${ }^{2}$, Roopika K. ${ }^{3}$, Sabitha Rani ${ }^{4} \&$ Rashmi D..$^{*}$ \\ ${ }^{1-5}$ Assistant Professor, Department of Biotechnology \& Microbiology, Padmashree Institute of Management and Sciences, \\ Bangalore-560060, Karnataka, India.Email id: rashmi.pcr@gmail.com ${ }^{5 *}$
}

DOI: http://doi.org/10.38177/ajast.2021.5312

Copyright: (C) 2021 Yamuna G. et al. This is an open access article distributed under the terms of the Creative Commons Attribution License, which permits unrestricted use, distribution, and reproduction in any medium, provided the original author and source are credited.

\section{ABSTRACT}

The present study was an effort to obtain paint degrading bacterial isolate from wall scrapings. The study included that microorganisms such as bacteria, not only cause discoloration of paint surfaces but also, they can directly cause degradation of the materials through their metabolic activities. The Halophilic microorganisms are well known for their paint degrading activity. As evidenced from the literature survey, there is a great diversity of bacteria and fungi that are capable of growing on paint coating. The presence of various polymer compounds used in paint manufacturing makes it resistant to degradation and continue to be a potential hazard to the environment as well as humans. Use of nonabrasive and environmentally safe methods, to reduce the impact of microbial activities can further reduce the damage as well as help in bioremediation of paint contaminated water soil and environments to clean up.

Keywords: Bioremediation, Contamination, Halophilic microbes, Polymers.

\section{Introduction}

Paint is one of the oldest synthetic substances known to mankind with a history stretching back into pre historic times (Karigar et.al, 2017). These are uniformly dispersed mixtures which have viscosity ranging from a thin liquid to a semisolid plate (Nwachukwu et.al, 2015). Paint is eventually a mixture of: Binder, solvent, pigment, thinner, drier, extender, additives, (Fichera et.al, 2015, Monico et.al, 2016, Fraga et.al, 2018, Hayashi et.al, 2019 \& Hewlett et.al, 2019).

The modern household paints fall into two broad categories, i.e.,

(a) 'orthodox', the oil-based or solvent-based paints, thinned with mineral turpentine or other organic solvents, and

(b) 'emulsion paints', the water-based vinyl or acrylic paints that may be thinned with water (Kanhar et.al, 2016).

\section{Degradation of paints}

Factors that influence deterioration of paints and paint products include the anaerobic environment in the paint, the organic nature of the paint's components, the microbial quality of the packaging materials and the hygiene level of the manufacturing plant processing units.

The consequence of their microbial deterioration such as foul smell, viscosity loss, discoloration and visible surface growth has serious economic, implication on the paint industry (Altenburg et.al, 2017).

\section{Health hazards}

Volatile organic compounds (VOC's) present in paint may lead to respiratory, allergic or immunogenic defects in humans (Mendell et.al, 2013). Frequently, paints contain a high level of mercury or lead and their ingestion may lead to serious health problems such as nerve and kidney damage. In addition, other metal such as chromium and cadmium are also reported that they provide many health risks. The exposure of VOCs has been related to organic 
solvents syndrome (Spurgeon et.al, 2006). The world health organisation (WHO) has reported a 20\%-40\% increased risk of certain types of cancer (particularly lung cancer).

\section{Bioremediation of paints}

Bioremediation involves in indigenous microbial populations with or without nutrient supplementation, or it can involve inoculation of exogenous organisms into the site to transfer or degrade toxic compounds to harmless or less toxic substances. Mohsen Zadeh et.al, (2012) have reported biological removal (bioremediation) treatment technology has turned out to be a favourable alternative because it produces no toxic end products and is cost effective. These processes typically relay on the use of aerobic indigenous microorganisms at site or enrichment with naturally occurring microorganisms to degrade the contaminants. Safia Ahmed et.al, (2018) have discussed bioremediation is nowadays a much widely acceptable technique due to its eco-friendly approach, although plenty of pollutant remedial technologies. Boopathy et.al, (2015) and Zakie et.al, (2016) have discussed the use of relatively cost effectively, non-invasive, and are attractive alternative for either pollutant treatment by successes during the present technology relay on appropriate microbes in appropriate habitat with supporting ecological conditions to detoxify the environmental paint pollutants in an open ecosystem.

\section{Microbial degradation}

Rosado et.al, (2013) stated that environmentalists have recently reported variety of microorganisms isolated from the paints having capability of biodegradation and bioremediation of paints and paint related wastes. Soudi and Kolahchi (2011) studied that the environment is contaminated with key pollutants could be an ideal source of the microbes utilizing or degrading them. The study conducted by Wojturska et.al, (2017) concerned the susceptibility of polyurethane coatings to enzymatic degradation. The authors studied the growth of bacteria in a culture medium using polyurethane coating as the sole source of carbon. They used the following bacteria; Pseudomonas, Corynebacterium, Bacillus and Brevibacterium. The entire microorganism in the study showed an ability to grow using polyurethane coating as a sole source of carbon.

\section{Microorganisms involved in degradation}

Gaylarde et.al, (2016) stated that major groups of microorganisms involved in paints deterioration are bacteria and fungi, which can grow on applied paint film and solvent and wanted based coatings. Jakubowski et.al, (2015) reported most commonly isolated bacterial and species in paints include Bacillus, Pseudomonas, Enterobacter, Proteus, Escherichia, Micrococcus, Serratia and Aeromonas. A wide range of anaerobic bacteria including Bacteriodes, Clostridium, Desulphovibrio and Bifidobacterium have also been isolated in paints (Opperman et.al, 2018). Rhizopus arrhinus, Aspergillus niger, Penicillium citrinum, Alternaria altanata fungi associated with the deterioration of paints (Grant et.al, 2017). The bacterial degradation of paints is faster than fungi to mineralize the paints through combined metabolic mode of aerobic anaerobic reaction in form of consortia (Chand et.al, 2016).

\section{Enzymatic biodegradation}

Cifferi et.al, (2016) have discussed due to the lack of water solubility and large size of polymer molecules the microorganism are unable to transport the polymeric materials directly into the cells, where most biochemical 
processes take place, so they are forced to produce certain enzymes which could penetrate the polymer and degrade them into smaller transportable molecules. Enzymes play an important role in metabolism and detoxification. The enzymes may be extracellular or intracellular and their mode of action will be different. Enzymatic degradation occurs by catalytic process. The enzymes can be denatured quickly by change in temperature or solvent or $\mathrm{pH}$. Some enzymes require coenzymes. Coenzymes act as a donor or acceptor for a specific group. Hydroxylases and oxygenase are the main enzymes used.

\section{Bacterial degradation of paint}

Ashwini et.al, (2018) reported on basis of their study on bacterial degradation of paint that microorganisms such as bacteria, not only cause discoloration of paint surfaces but also, they can directly cause degradation of the materials through their metabolic activities. The bacterial isolates also vary with the type of paint used. The microbes isolated in the study, has used paint as the sole source of carbon for its growth and metabolic activity and contributed towards the degradation of the paint materials.

The presence of acrylic compound in the paint samples inhibits growth of many organisms which made the isolation process tedious. Reports on fungal isolation from paint are quite common than bacteria. The following bacteria showed the ability to grow by utilizing paint: Bacillus, Brevibacterium, Pseudomonas, Lactobacillus sp.

\section{Materials and Methods}

\section{Sample collection}

Paint flakes were collected from 20 different places. The sample was collected in different containers which were properly sealed. The sealed individual containers are labelled neatly and moved to laboratory for further analysis.

\section{Isolation of bacteria from wall scrapings}

Mineral salt medium was used to isolate the bacteria from paint samples. Mineral salt medium was prepared, where paint acted as the sole source of carbon. Media was sterilised for 20 minutes at $121^{\circ} \mathrm{C}$ at $15 \mathrm{lbs}$. The flask was allowed to reach the room temperature. The pHis checked and adjusted to 7.2 using $1 \mathrm{~N} \mathrm{NaOH}$ or $1 \mathrm{~N} \mathrm{HCL}$. 1gm of paint flakes were added into the medium aseptically and incubated at room temperature for 7 days.

\section{Screening of bacterial isolates for their paint degrading potentiality}

\section{Screening of bacterial isolates on mineral salt agar media amended with oil emulsion}

Mineral salt agar medium was prepared, sterilized at $121^{\circ} \mathrm{C}$ for 20 minutes at $15 \mathrm{lbs}$ and plated in sterilized petri plates and left for solidification. After the media got solidified $0.1 \mathrm{ml}$ of sample was transferred to mineral salt agar medium and spread plating was carried out. The inoculated plates were incubated at $37^{\circ} \mathrm{C}$ for 24 hours.

\section{Screening of bacterial isolates on LB agar media amended with oil emulsion}

LB agar was prepared, sterilized at $121^{\circ} \mathrm{C}$ for 20 minutes at $15 \mathrm{lbs}$ and plated in pre -sterilized petri plates and left for solidification. After the media got solidified $0.1 \mathrm{ml}$ of sample was transferred to mineral salt agar medium and spread plating was carried out. The inoculated plates were incubated at $37^{\circ} \mathrm{C}$ for 24 hours. 


\section{Biochemical studies on different bacterial isolates}

- IMViC, Oxidase test, Catalase test, Urease production, Starch hydrolysis

- Growth at different incubation temperatures $\left(10^{\circ} \mathrm{C}, 15^{\circ} \mathrm{C}, 25^{\circ} \mathrm{C}\right.$ and $\left.45^{\circ} \mathrm{C}\right)$

- Growth at different $\mathrm{pH}(2,5,7$ and 9)

\section{Screening of paint degrading potentiality of bacterial secondary metabolites}

The paint degrading potentiality of the secondary metabolites was screened by observing the leaching of the paint from the pre coated metal strips treated with the crude bacterial extract having desirable concentration. Thin metal strips were coated with oil emulsion with the approximate thickness of $0.001 \mathrm{~mm}$ and allowed to dry. The dried metal stripes were immersed in sterile distilled water containing crude bacterial extracts at the concentration of $1 \mathrm{mg} / \mathrm{ml}$. The whole setup was incubated at room temperature for 48 hours and observed for leaching of the paint. Coated metal strip in distilled water served as negative control, coated metal strip in 1N HCL was positive control.

\section{Molecular identification of biologically active bacterial isolates}

For the molecular identification of bio active bacterial isolates exhibiting exhibiting paint degrading capacity, DNA extraction, amplification was done using forward (27F-50-AGAGTTTGATCCTGGCTCAG-30) and reverse (1492R-50ACGGCTACCTTGTTACGC TT-30) primers (Genie, Bangalore, India), according to the protocol followed by Aman and Rai, (2016). Final PCR amplicon was eluted in 1.5\% agarose gel and purified using GenElute gel elution kit (Sigma Aldrich, USA). Sequencing of DNA was accomplished and blast analysis was done. Similarities of Nucleotides were determined by NCBI (National Centre for Biotechnology Information databases). The identified isolate sequence was deposited and allotted with accession number.

\section{Phylogenetic analysis of bacterial isolates}

$16 \mathrm{~S}$ rDNA sequences obtained from bioactive bacterial isolates were homologically aligned with reference sequences from NCBI database with the aid of multiple sequence alignment program of MEGA 4.0 (Tamura, et.al, 2007). Unrooted phylogenetic tree was constructed using neighbour-joining and was maintained by 1000 boot straps using the MEGA-5 software.

\section{Result and Discussion}

\section{Isolation and characterization of bacteria from wall scrapings}
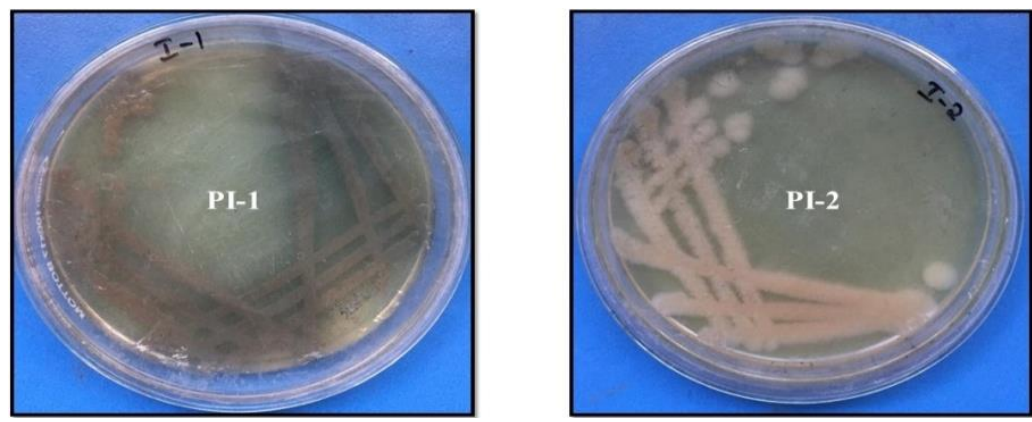

Fig.1. Bacterial isolates of wall scrapings on LB agar 

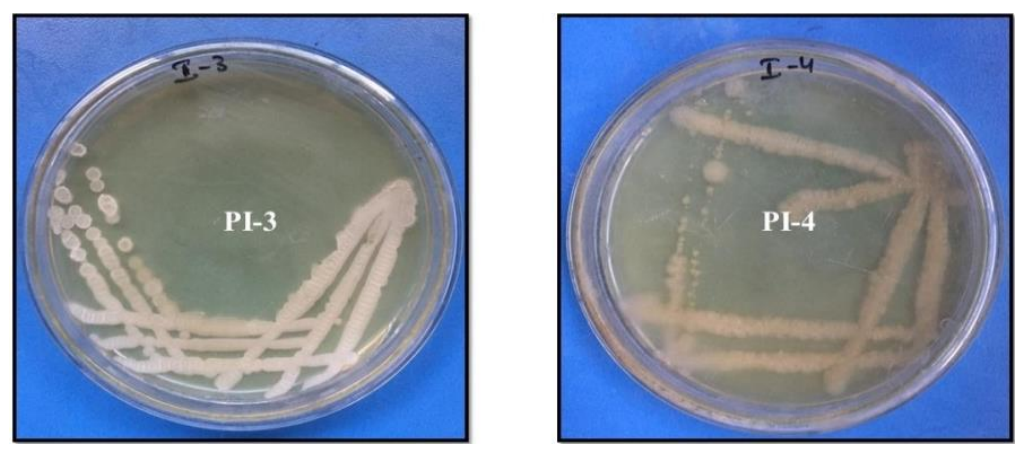

Fig.2. Bacterial isolates of wall scrapings on LB agar
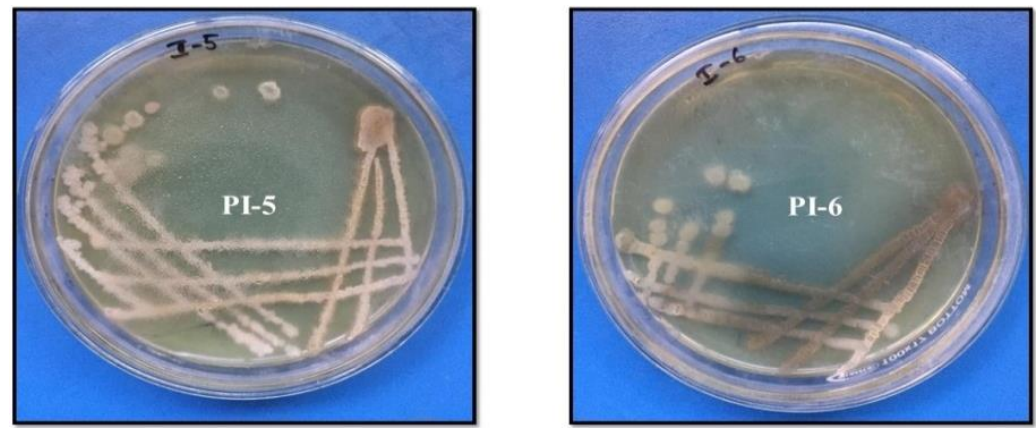

Fig.3. Bacterial isolates of wall scrapings on LB agar

Growth was observed on LB agar plates. Among six isolates PI-1, PI-5 and PI-6 was found to be gram negative rods. PI-2, PI-3 and PI-4 was found to be gram positive rods (Figs. 1,2 and 3).

\section{Biochemical studies on different bacterial isolates}

Identification of isolated culture was done by conduction of microbiological and biochemical test as referred in Bergey 's manual Whitmanet.al, (2012). The results of various test \& tabulated.

The organism showed:

1. All organisms showed indole negative.

2. $66.66 \%$ positive and $33.33 \%$ negative for methyl red test.

3. All organism showed negative for voges-proskauer test.

4. All organisms showed positive for citrate utilization test.

5. $66.66 \%$ positive and $33.33 \%$ negative for urease test.

6. All organisms showed positive for catalase test.

7. $50 \%$ positive and $50 \%$ negative for oxidase test.

8. $66.66 \%$ positive and $33.33 \%$ negative for starch hydrolysis. 


\section{Physiological characterization}

Table 1. Growth of isolates at different $\mathrm{pH} \&$ temperatures

\begin{tabular}{|c|c|c|c|c|}
\hline \multirow{2}{*}{ Samples } & \multicolumn{4}{|c|}{ pH } \\
\hline & 2 & 5 & 7 & 9 \\
\hline Control & - & - & - & + \\
\hline P.I-1 & - & + & + & + \\
\hline P.I-2 & - & - & + & + \\
\hline P.I-3 & - & - & + & + \\
\hline P.I-4 & - & + & + & + \\
\hline P.I-5 & - & + & + & + \\
\hline P.I-6 & - & + & + & + \\
\hline \multirow{2}{*}{ Samples } & \multicolumn{4}{|c|}{ Temperature } \\
\hline & $4^{\circ} \mathrm{C}$ & $15^{\circ} \mathrm{C}$ & $27^{\circ} \mathrm{C}$ & $37^{\circ} \mathrm{C}$ \\
\hline Control & - & - & + & - \\
\hline P.I-1 & - & - & + & + \\
\hline P.I-2 & - & + & + & + \\
\hline P.I-3 & - & - & + & + \\
\hline P.I-4 & - & - & + & + \\
\hline P.I-5 & - & + & + & + \\
\hline P.I-6 & - & - & + & + \\
\hline
\end{tabular}

Key: $(+)=$ positive and $(-)=$ negative

None of the isolates were able to grow at $\mathrm{pH} 2$ and two isolates were not able to grow at $\mathrm{pH} 5$. At $\mathrm{pH} 7$ and 9 all organism showed positive growth (Table 1).

All organisms showed negative growth at $4^{\circ} \mathrm{C}$ and four isolates were not able to grow at $15^{\circ} \mathrm{C}$. All the organisms showed positive growth at $27^{\circ} \mathrm{C}$ and $37^{\circ} \mathrm{C}$ (Table 2).

\section{Paint degrading potentiality of bioactive bacterial isolates on precoated metal strips}

\section{Secondary metabolite extraction}

By the addition of ethyl acetate for supernatant obtained, secondary metabolite present in bacteria are dissolved and precipitation was seen (Fig.4).
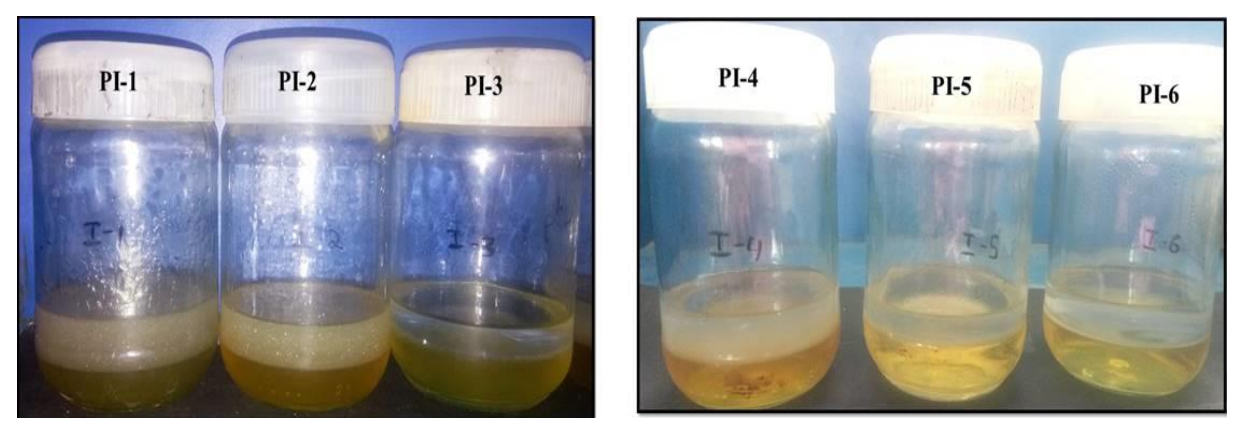

Fig.4. Secondary metabolites extraction 
Leaching of paint was observed on the metal strip that was coated with paint. Graph was plotted using the optical density taken (Fig.5).

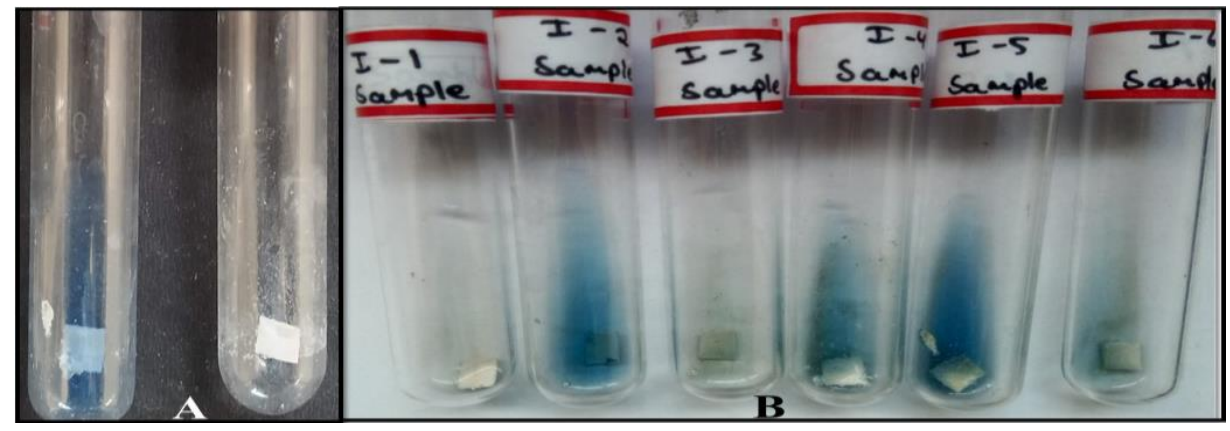

Fig.5. $\mathrm{A}=+\mathrm{ve}$ control and $-\mathrm{ve}$ control and $\mathrm{B}=$ samples showing paint leaching

The graph was plotted on the basis of OD value taken. Comparison of positive and negative control with six isolates indicated that PI-4 was showing more degradation (Graph 1).

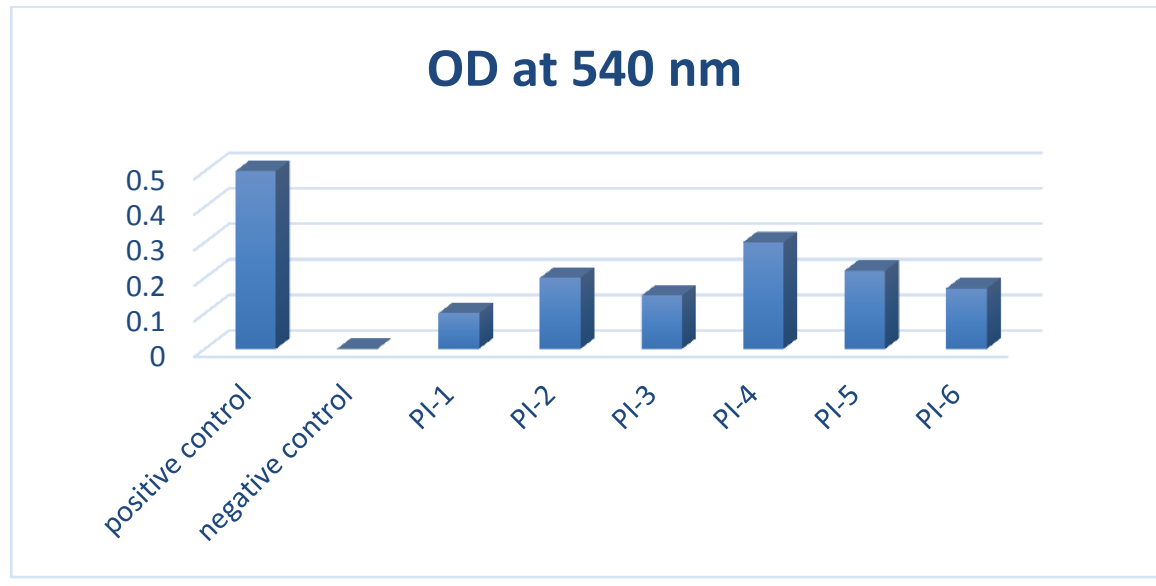

Graph 1. Isolates showing rate of degradation

\section{Molecular identification and phylogenetic analysis}

Molecular identification was done by amplifying genomic DNA followed by sequencing of $16 \mathrm{~s}$ rRNA gene. Isolate was identified by The Basic Local Alignment Search Tool (BLAST) analysis of obtained 16s rRNA sequence. Further we concluded PI-4 isolate as Brevibacterium sp by phylogenetic analysis.

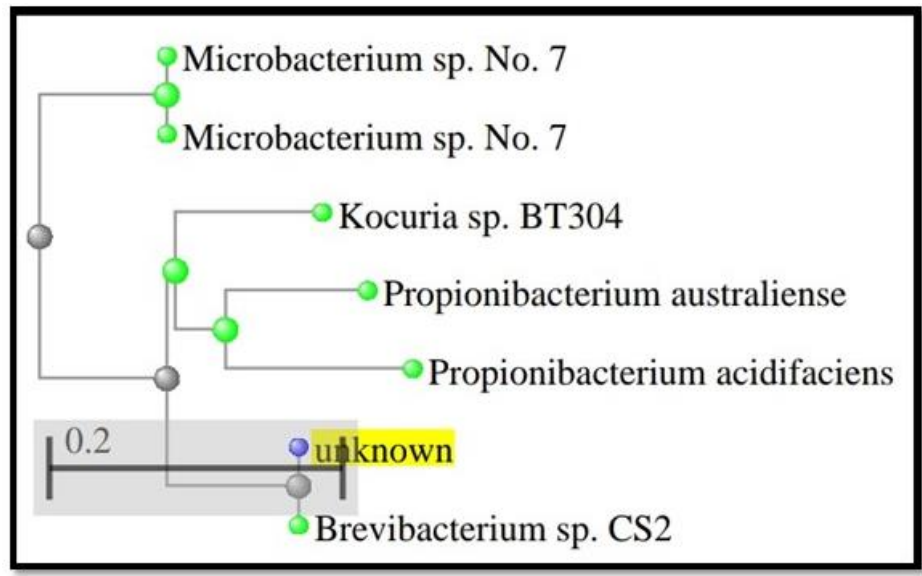

Fig.6. Phylogenetic tree of PI-4 isolate 


\section{Conclusion}

The present study was an effort to obtain paint degrading bacterial isolate from wall scrapings. It concludes that microorganisms such as bacteria, not only cause discoloration of paint surfaces but also, they can directly cause degradation of the materials through their metabolic activities. Several microorganisms are well known for their paint degrading activity. As evidenced from the literature survey, there is a great diversity of bacteria and fungi that are capable of growing on paint coating. The presence of various polymer compounds used in paint manufacturing makes it resistant to degradation and continue to be a potential hazard to the environment as well as humans. Use of nonabrasive and environmentally safe methods, to reduce the impact of microbial activities can further reduce the damage as well as help in bioremediation of paint contaminated water, soil and environments to clean up.

\section{Declarations}

\section{Source of Funding}

This research did not receive any grant from funding agencies in the public, commercial, or not-for-profit sectors.

\section{Competing Interests Statement}

The authors declare no competing financial, professional and personal interests.

\section{Ethical Approval}

Based on Institutional guidelines.

\section{Consent for publication}

Authors declare that they consented for the publication of this research work.

\section{References}

1. Aina, V. O., Adewumi, A. A. J., Haruna, H., \& Zakari, A. (2011). Isolation and identification of fungi associated with the deterioration of painted wall surfaces within Kaduna Polytechnic. Asian J. of Med. Sci., 3(6), 250-253.

2. Altenburgera, P., Kämpferb, P., Makristathisc, A., Lubitza, W., \& Bussea, H. J. (1996). Classification of bacteria isolated from a medieval wall painting. Journal of biotechnology, 47(1), 39-52.

3. Amara, I., Miled, W., Slama, R. B., \& Ladhari, N. (2018). Antifouling processes and toxicity effects of antifouling paints on marine environment. A review. Environmental toxicology and pharmacology, 57, 115-130.

4. Anele, B. C., Okerentugba, P. O., Stanley, H. O., \& Ugboma, C. J. (2019). Biodeterioration of Classroom Wall Surfaces in the University of Port Harcourt, Nigeria. Journal of Advances in Microbiology, 1-8.

5. Ashwini, R., \& Anchana, D. (2018). "Bacterial degradation of paint”. International Journal of Biology Research, 3(1), 180-184.

6. Awodele, O., Popoola, T. D., Ogbudu, B. S., Akinyede, A., Coker, H. A., \& Akintonwa, A. (2014). Occupational hazards and safety measures amongst the paint factory workers in lagos, Nigeria. Safety and health at work, 5(2), 106-111. 
Asian Journal of Applied Science and Technology (AJAST)

Volume 5, Issue 3, Pages 126-137, July-September 2021

7. Aykin, E., Omuzbuken, B., \& Kacar, A. (2019). Microfouling bacteria and the use of enzymes in eco-friendly antifouling technology. Journal of Coatings Technology and Research, 16(3), 847-856.

8. Baij, L., Hermans, J. J., Keune, K., \& Iedema, P. (2018). Time-Dependent ATR-FTIR Spectroscopic Studies on Fatty Acid Diffusion and the Formation of Metal Soaps in Oil Paint Model Systems. AngewandteChemie International Edition, 57(25), 7351-7354.

9. Banti, D., La Nasa, J., Tenorio, A. L., Modugno, F., van den Berg, K. J., Lee, J., \& Bonaduce, I. (2018). A molecular study of modern oil paintings: investigating the role of dicarboxylic acids in the water sensitivity of modern oil paints. RSC Advances, 8(11), 6001-6012.

10. Carstens, L. E. (2018). The impact of multinational corporations on the marketing mix of a South African architectural coatings manufacturer (Doctoral dissertation, North-West University (SA), Potchefstroom Campus).

11. Caselli, E., Pancaldi, S., Baldisserotto, C., Petrucci, F., Impallaria, A., Volpe, L., \& Bevilacqua, F. (2018). Characterization of biodegradation in a 17 th century easel painting and potential for a biological approach. PloS one, 13(12), e0207630.

12. David, B., Delannoy, J. J., Petchey, F., Gunn, R., Huntley, J., Veth, P., \& Ouzman, S. (2019). Dating painting events through by-products of ochre processing: Borologa 1 Rockshelter, Kimberley, Australia. Australian Archaeology, 1-38.

13. Eliaz, N., Ron, E., Gozin, M., Younger, S., Biran, D., \& Tal, N. (2018). Microbial Degradation of Epoxy. Materials, 11(11), 2123.

14. Enea, D., Bellardita, M., Scalisi, P., Alaimo, G., \& Palmisano, L. (2019). Effects of weathering on the performance of self-cleaning photocatalytic paints. Cement and Concrete Composites, 96, 77-86.

15. English, S. E., Fjelde, S., Greenhalgh, M., McCabe, R. W., Mc Kenna, T., Morton, L. H. G., \& Sherrington, I. (2003). Laboratory and field studies on thin paint films. Int. biodeterioration \& biodegradation, 52(4), 247-253.

16. Ghazali, Z., \& Aigbogun, O. (2019). Information Source and Media Channel Preference of Malaysian Consumers: A Perception study on Lead-based Household Paints Hazards. Platform: A Journal of Management and Humanities, 1(1), 47-55.

17. Gorbushina, A. A., \& Petersen, K. (2000). Distribution of microorganisms on ancient wall paintings as related to associated faunal elements. International Biodeterioration \& Biodegradation, 46(4), 277-284.

18. Gupta, S., \& Vora, S. M. (2018). Colour Academy, a CSR Initiative of Asian Paints: Valuation \& Analysis of its Social Impact. Anvesha, 11(2).

19. Hashim, Z., Mohd Hafiz, S. T., Naing, L., Hashim, J. H., \& Rusli, N. (2013). Occupational Xylene Exposure and Respiratory Impairment of Paint Manufacturing Workers. International Journal of Medicine and Medical Sciences, 5(5), 214-220.

20. Horn, K. R. (2018). Time takes its toll: Detection of organic binder media in ochre paints with visible near-infrared and short-wave infrared reflectance spectroscopy. Journal of Archaeological Science: Reports, 21, $10-20$. 
Asian Journal of Applied Science and Technology (AJAST)

Volume 5, Issue 3, Pages 126-137, July-September 2021

21. Hunsaker, A. J., \& Rocke, L. (2019). Street art in the library: Transforming spray paint into a digital archive and virtual reality experience. Journal of Digital Media Management, 7(3), 279-291.

22. Ishfaq, S., Ali, N., Tauseef, I., Khattak, M. N. K., Shinwari, Z. K., \& Ali, M. I. (2015). Analysis of paint degradation by fungal and bacterial species. Pakistan Journal of Botany, 47(2), 753-760.

23. Karasa, J., Kostjukovs, J., Pals, M., \& Kostjukova, S. (2018). Eco friendly clay base multifunctional additive improving paint resistance towards degradation processes including UV radiation. International Multidisciplinary Scientific GeoConference: SGEM: Surveying Geology \& mining Ecology Management, 18, 129-134.

24. Kennedy, C., Lordo, R., Sucosky, M. S., Boehm, R., \& Brown, M. J. (2016). Evaluating the effectiveness of state specific lead-based paint hazard risk reduction laws in preventing recurring incidences of lead poisoning in children. International journal of hygiene and environmental health, 219(1), 110-117.

25. Khan, K. A. (2018). Marketing for Rural Markets in India. Indian Rural Market: Opportunity and Challenges in the Global Context, 1(1), 305-310.

26. Królikowska, A., Komorowski, L., \& Bonora, P. L. (2019). Hidden Reason of Paint System Delamination.

27. Krolikowski, S., Rampf, M., Ritzberger, C., Bürke, H., Holand, W., \& Schweiger, M. (2019). U.S. Patent Application No. 16/156,203.

28. Kurowski, G., Vogt, O., \& Ogonowski, J. (2017). Paint-degrading microorganisms. CzasopismoTechniczne, 2017(Volume 12), 81-92.

29. Kurtböke, İ., Ivshina, I., \& Blackall, L. L. (2018). Microbial biodeterioration and biodegradation. Microbiology Australia, 39(3), 115-116.

30. Lagerström, M., Yngsell, D., Eklund, B., \& Ytreberg, E. (2019). Identification of commercial and recreational vessels coated with banned organotin paint through screening of tin by portable XRF. Journal of hazardous materials, 362, 107-114.

31. Lingvay, I., Fortuna, L., Varga, E., Bors, A. M., \& Lingvay, D. (2018). Durability and Anticorrosive Protection Capability of Paint Layers-Biological Factors Influence. Electrotehnica, Electronica, Automatica, 66(4).

32. Maggos, T., Bartzis, J. G., Liakou, M., \& Gobin, C. (2007). Photocatalytic degradation of NOx gases using TiO2-containing paint: A real scale study. Journal of hazardous materials, 146(3), 668-673.Hare, C. H. (2002). Paint Film Degradation Mechanisms and Control.

33. Maksoud, N. A., Aal, K. A., Ghandour, N., El-Baz, M., \& Shaltout, E. (2018). Assessment of Hematotoxicity and Genotoxicity among paint Workers in Assiut Governorate: a case control study. Egyptian J. of For. Sci., 8(1) 6. 34. Mohamed, G. N. A. D. A., \& Adam, A. I. A. The Role of Total Quality Management on Improving Supply Chain practices Case study: Nile Paints Company.

35. Mukherjee, A., Joshi, M., Misra, S. C., \& Ramesh, U. S. (2019). Antifouling paint schemes for green SHIPS. Ocean Engineering, 173, 227-234.

36. Obidi, O. F., Aboaba, O. O., Makanjuola, M. S., \& Nwachukwu, S. C. U. (2009). Microbial evaluation and deterioration of paints and paint-products. Journal of environmental biology, 30(5), 835 . 
Asian Journal of Applied Science and Technology (AJAST)

Volume 5, Issue 3, Pages 126-137, July-September 2021

37. Obidi, O., Nwachukwu, S., \& Aboaba, O. (2010). Investigation on the Biodegradative Potential of Pseudomonas aeruginosa on Water-based Paints.

38. Okunye, O. L., Morakinyo, K. O., \& Ayedun, J. S. (2013). Isolation and characterization of fungi associated with in-can degradation of paint. Journal of Environment and Earth Science, 3(12), 142-145.

39. Onuoha, O. (2018). Studies On The Causes Of Emulsion Paint Degradation On Buildings In Port Harcourt, Nigeria And Paint Forming Properties Of Some African Seed Oils.

40. Parody, A., Viloria, A., Lis, J. P., Malagón, L. E., Calí, E. G., \& Palma, H. H. (2018, June). Application of an experimental design of D-optimum mixing based on restrictions for the optimization of the pre-painted steel line of a steel producer and marketing Company. In International Conference on Data Mining and Big Data (pp. 729-738). Springer, Cham.

41. Phulpoto, A. H., Qazi, M. A., Mangi, S., Ahmed, S., \& Kanhar, N. A. (2016). Biodegradation of oil-based paint by Bacillus species monocultures isolated from the paint warehouses. International journal of environmental science and technology, 13(1), 125-134.

42. Phulpoto, A. H., Qazi, M. A., Mangi, S., Ahmed, S., Phul, A. R., \& Kanhar, N. A. (2017). Bioremediation of Oil-Based Paint from Aqueous Media by Novel Indigenous Brevibacillusparabrevis Strain NAP3 and its Toxicity Assessment. Polish Journal of Environmental Studies, 26(1).

43. Piemonte, V., Francioni, F., Capocelli, M., \& Prisciandaro, M. (2017). Biodegradation of acrylic paints: process modelling of biocide effect on biomass growth at different temperatures. Brazilian Journal of Chemical Engineering, 34(2), 557-566.

44. Ravikumar, H. R., Rao, S. S., \& Karigar, C. S. (2012). Biodegradation of paints: a current status. Indian Journal of Science and Technology, 5(1), 1977-1987.

45. Salihoglu, G., \&Salihoglu, N. K. (2016). A review on paint sludge from automotive industries: Generation, characteristics and management. Journal of environmental management, 169, 223-235.

46. Shcherbakova, M. S., Shutilin, Y. F., \& Moiseyev, V. V. (2013). Vliyaniyesostavalakokrasochnogomaterial anasvoystvapokrytiy [Influence of the composition of paint on the properties of coatings]. Vestnik VGUIT, (1), 55. 47. Turner, D. A., Williams, M., Sigman, M. A., \& Goodpaster, J. V. (2018). A comprehensive study of the alteration of ignitable liquids by weathering and microbial degradation. Journal of forensic sciences, 63(1), 58-65.

48. Ugbogu, O. C., Awache, I., Agwaranze, D. I., Ogodo, A. C., Ubandoma, A., \& Yakubu, M. N. (2017). Microbial deterioration of painted wall surfaces in Wukari, Taraba State, Nigeria. American Journal of Microbiology and Biotechnology, 4, 31-34.

49. Unković, N., LjaljevićGrbić, M., Stupar, M., Vukojević, J., Subakov-Simić, G., Jelikić, A., \& Stanojević, D. (2019). ATP bioluminescence method: tool for rapid screening of organic and microbial contaminants on deteriorated mural paintings. Natural product research, 33(7), 1061-1069.

50. Urbanczyk, M. M., Bester, K., Borho, N., Schoknecht, U., \& Bollmann, U. E. (2019). Influence of pigments on phototransformation of biocides in paints. Journal of hazardous materials, 364, 125-133. 
51. Van Driel, B. A., van den Berg, K. J., Smout, M., Dekker, N., Kooyman, P. J., \& Dik, J. (2018). Investigating the effect of artists' paint formulation on degradation rates of TiO 2-based oil paints. Heritage Science, 6(1), 21.

52. Wuana, R. A., \& Okieimen, F. E. (2011). Heavy metals in contaminated soils: a review of sources, chemistry, risks and best available strategies for remediation. Isrn Ecology, 2011.

53. Whitman, W. B, W., Euzéby, J., Schumann, P., Busse, H. J., Trujillo, M. E., Kämpfer, P., \& Ludwig. (2012). Road map of the phylum Actinobacteria. In Bergey’s manual ${ }^{\circledR}$ of systematic bacteriology (pp. 1-28). Springer, New York, NY. 